\title{
The effects of periparturient events, mastitis, lameness and ketosis on reproductive performance of Holstein cows in a hot environment
}

\author{
Miguel Mellado ${ }^{a}$, José E. García ${ }^{a}$, Francisco G. Véliz Deras ${ }^{b}$, María de los Ángeles de Santiago ${ }^{b}$, \\ Jesús Melladoa , Leticia R. Gaytán ${ }^{\mathrm{b}}$, Oscar Ángel-García ${ }^{\mathbf{b}}{ }^{*}$
}

\begin{abstract}
The aim of this study was to determine the association among periparturient events such as mastitis, lameness (infectious and non-infectious) and ketosis and the reproductive performance of high producing Holstein cows in a hot environment. The health status and reproductive data variables were recorded from 6,566 completed lactations in a large dairy operation. A logistic regression model with the stepwise procedure was used, considering the occurrence of the health problems during the pre-breeding period as fixed effect risk factors and reproductive variables as dependent variables. Pregnancy rate of cows contracting clinical mastitis $(\mathrm{CM})$ around the period of first inseminations was five percentage points lower than cows without this disease. Cows with CM shortly before or after the first service had twice the risk of requiring more than three services per pregnancy than cows with healthy udders. Cows experiencing abortion, laminitis or metritis were two times more likely to require $>3$ services per pregnancy than cows not experiencing these reproductive disorders. Cows experiencing lameness, mastitis and metritis presented a significantly longer interval between calving and pregnancy compared to healthy cows. Ketosis and lameness increased the odds of a cow of being inseminated for the first time after 70 days in milk. In conclusion, these results suggest that abortion, ketosis, CM, retained placenta (RP), metritis, and lameness are associated with decreased reproductive performance in high producing Holstein cows subjected to thermal stress.

Key words: Holstein cows, days open, services per conception, laminitis, metritis.
\end{abstract}

\section{INTRODUCTION}

In order to be successful and remain competitive, milk producers must minimise losses from infertility. Factors that affect fertility include both herd-level management and individual cow factors. In this case, clinical reproductive diseases cause not only short-term problems and milk yield losses, but also they have long-term harmful effects on fertility (Roche et al 2000). Moreover, cows that present periparturient diseases are more susceptible to develop other diseases (Opsomer et al 2000, Williams et al 2007); thus, a healthy passage through the transition period is essential for proper reproductive efficiency in dairy cows. The assessment of the impact of gynecological diseases on the overall level of reproductive processes has been well documented in European dairy cattle in temperate climates (Dubuc et al 2010, Gilbert 2011). A great number of these studies were carried out in herds with two milkings per day, without the use of recombinant bovine somatotropin (rbST) throughout lactation and at latitudes where heat load is not a serious hurdle for dairy operations.

Genetic selection for milk production coupled with improved management and the use of rbST throughout lactation markedly increases milk yield. This, in turn, increases the lactating dairy cows' susceptibility to metabolic

Accepted: 02.08.2017.

aDepartamento de Nutrición Animal, Universidad Autónoma Agraria Antonio Narro, Saltillo, México.

bDepartamento de Ciencias Veterinarias, Universidad Autónoma Agraria Antonio Narro, Torreón, México.

*Corresponding author: O Ángel-García; Periférico Raúl López Sánchez S/N, Torreón, Coahuila, México, C.P. 27000; mvz.oscar_2207@hotmail.com diseases (Roche et al 2009), and negatively affects uterine disease health (Lucy 2001, Bonneville-Hébert et al 2011), foot problems health (Bicalho et al. 2008) and reproductive disorders (Gröhn and Rajala-Schultz 2000). Additionally, the incidence of double ovulation is greater in high yielding cows (Fricke and Wiltbank 1999, Fitzgerald et al 2014) and twining is associated with occurrence of pregnancy losses (Silva del Rio et al. 2009), neonatal calf mortality (Silva del Río et al 2007), abortion, dystocia, stillbirth and retained placenta (RP) (Echternkamp et al 2007), which collectively exert adverse influences on reproduction. Thus, it is pertinent to evaluate the impact of some periparturient disorders, lameness, mastitis and ketosis in cows with 305 -d lactations producing $>12,000 \mathrm{~kg}$, kept under intense management ( $3 \mathrm{x}$ milking plus rbST administration throughout lactation) and subjected to a relentless heat load for the most part of the year.

The goal of this research was to investigate the relationship between some common periparturient diseases and metabolic conditions of dairy cows and breeding performance in a herd of high producing Holstein cows. The hypothesis tested was that the occurrence of gynecological, metabolic, locomotion and udder diseases during the voluntary waiting period are associated with reduced reproductive performance.

\section{MATERIAL AND METHODS}

\section{STUDY HERD, HOUSING AND FEEDING}

The experimental procedures and animal care conditions were approved by the Ethics Committee of the Research Department of the Autonomous Agrarian University Antonio Narro. The study was conducted on a large commercial 
dairy herd located in northeastern Mexico $\left(26^{\circ} \mathrm{N}\right.$, elevation $1140 \mathrm{~m}$, mean annual temperature $23.7^{\circ} \mathrm{C}$, mean annual rainfall $230 \mathrm{~mm}$ ). This zone is characterised by high daytime temperatures in spring, summer and fall (around $40{ }^{\circ} \mathrm{C}$ ) and intense solar radiation associated with low relative humidity while nights are warm. The study began in January 2010 and ended in December 2011. The herd consisted of approximately 7500 Holstein cows housed in open, dirt pens and managed in groups according to lactation, production, and reproductive status. All pens were equipped with evaporative coolers, which injected a fine mist of water into turbulent air from electric fans installed on shade roofs during the warm season. Fans and water sprinklers were activated automatically when ambient temperature reached $26{ }^{\circ} \mathrm{C}$.

Cows were fed total mixed diets (50\% forage and $50 \%$ concentrate; DM basis) formulated to meet or exceed NRC requirements for lactating dairy cows producing $>33 \mathrm{~kg}$ of milk/d (NRC, 2001), with $1.62 \mathrm{Mcal} / \mathrm{kg} \mathrm{NEl}$ and $18 \%$ crude protein. Cows were fed ad libitum for a daily feed refusal of approximately $10 \%$ of that offered, 4 times daily at 06:00, 10:00, 12:00, and 16:00 h.

Cows were milked, throughout the study, three times daily (06:00, 14:00, and 21:00 h). All cows were subjected to recombinant bovine somatotropin (rbST; Lactotropin, $500 \mathrm{mg}$ of zinc bovine somatotropin, Elanco Animal Health, Mexico) administrated subcutaneously every 14 $\mathrm{d}$ beginning at 60 DIM and continuing until $2 \mathrm{wk}$ before drying off.

Cows included in the study were in their first to eight lactations, with body condition score ranging from 2.75 to 3.5 (scale 1 to 5 ). The 305 -day rolling herd average was about $12,200 \mathrm{~kg}$ throughout the study. Average number of times inseminated was 3.7 (range $=1$ to 14 inseminations). Average DIM per lactation was $334(\mathrm{SD}=89)$.

\section{HEALTH MANAGEMENT AND DISEASES DEFINITION}

The last day of milking, cows received an intramammary infusion of $375 \mathrm{mg}$ cephalexin (Rilexine ${ }^{\circledR}$, Virbac, Mexico) per quarter. Additionally, cows received a slow release bolus containing various microminerals and vita$\min A, D$, and E (Megabric $®$, Neolite laboratory, France). Routine mastitis control included a thorough udder washing before milking, disinfection, pre-and post-milking teat dipping, strip cup test at milking, and regular somatic cell counting. Occurrence of clinical mastitis (CM) was detected by milkers upon observing a hard-swollen warm udder and changes in milk consistency (watery or bloodtinged secretions and clots in milk). Only cows presenting CM up to two weeks before the first breeding and after six weeks after the beginning of breeding were included in the analysis.

Specific microorganisms causing bovine intramammary infections were not determined. Cows with mastitis received an intramammary treatment with broad spectrum antibiotics (tetracycline, neomycin, bacitracin and prednisolone; Mastivac NRV®, Norvet, Torreon, Mexico).

Retained placenta (RP) is defined as failure to expel fetal membranes within $24 \mathrm{~h}$ of calving is a pathological condition (Dervishi et al. 2016) and was diagnosed based on the presence of fetal membranes protruding from the vulva for over $24 \mathrm{~h}$ after calving. Metritis is defined as the inflammation that involves the entire thickness of the uterine wall (Sheldon et al. 2006). This was confirmed by assessing, by rectal palpation, the size of the uterus as related to time of calving, recording the thickness of the uterine wall and the presence of fluid draining from one or both horns. Metritis was treated with an intrauterine infusion of $1500 \mathrm{mg}$ oxytetracycline hydrochloride solution and an intramuscular injection of $25 \mathrm{mg}$ PGF2 $\alpha$ ( $5 \mathrm{ml}$ of Lutalyse, Upjohn, Mexico).

Lameness was classified into two categories: (1) infectious interdigital disease which included digital dermatitis (hairy heel warts) and heel horn erosion and foot rot (interdigital phlegmon, interdigital necrobacillosis), and (2) lameness produced by a variety of claw horn lesions such as white line and sole ulceration, digital disease (white line abscess, haemorrhage or fissure, foreign bodies in the sole and pricked or punctured sole).

Feet wounds were debrided of necrotic tissue, cleaned and local antiseptics (iodine tincture) were applied. Systemic therapy consisting of 5 days of antibiotic therapy (sulfamonomethoxine and trimethoprim, Daimetom ${ }^{\circledR}$, Sanfer, Mexico) was used to hasten recovery. Corrective foot trimming was done when necessary.

Abortion was defined as fetal death and expulsion between 50 and 260 days of gestation (the condition did not include fetal mummification). These cows received and intrauterine infusion of $1 \mathrm{~g}$ gentamicin (this drug is approved for use in animals in Mexico) and $2 \mathrm{~g}$ tylosin in $100 \mathrm{ml}$ saline (GT 300® laboratories Pier, Tehuacan, Mexico).

Cows presenting RP were treated with a 8,000,000 I.U. combination of penicillin and streptomycin (Antibioserva ${ }$, MSD Animal Health, Mexico), plus 25 mg estradiol benzoate (ECP®, Pharmacia \& Upjohn, Mexico), tylosin, gentamicin, dexamethasone and chlorphenamine (TyloCombisone ${ }^{\circledR}$, Vetermex, Mexico) and $25 \mathrm{mg} \mathrm{PGF}_{2 \alpha}$ (Lutalyse®, Pharmacia \& Upjohn, Inc, Mexico). Ketosis was diagnosed by the veterinarian based on lowered milk yield and decreased appetite associated with a positive urine strip test for ketone bodies (Ketostix $®$, Bayer Mexico, Mexico D.F.). Cows with ketosis were drenched daily for three days with $500 \mathrm{ml}$ propylene glycol.

\section{REPRODUCTIVE MANAGEMENT}

Cows were routinely vaccinated against diseases that impair reproductive functions, such as bovine viral diarrhea, infectious bovine rhinotracheitis, bovine respiratory syncytial virus, para-influenza and leptospirosis (5 varieties). 
The voluntary waiting period for cows was $50 \mathrm{~d}$. Cows were administered a single injection of $\mathrm{PGF}_{2 \alpha}$, at 25 to $32 \mathrm{~d}$ postpartum for a cleansing effect on the uterine environment. Cows received typical reproductive management: detection of estrus at 08:00 and 17:00 $\mathrm{h}$ with the a.m.-p.m. breeding rule. $\mathrm{PGF}_{2 \alpha}$ and $\mathrm{GnRH}$ were used occasionally when determined to be appropriate by the herd veterinarian. The AI was performed by well-trained herd personnel. Pregnancy status was assessed 45-50 days after AI by transrectal palpation, which was conducted by the herd veterinarian, if the diagnosis was unsure, cows were reevaluated $1 \mathrm{wk}$ later.

Breeding and health records representing 6,566 parturitions were analysed. Data were screened to include only those cows that were lactating, had at least one service, or a maximum of 10 services (due to low conception rates in this dairy herd caused by heat stress, many cows continued to be inseminated beyond 250 days in milk, which sometimes led to $>10$ services), had an interval from to calving first service greater than $40 \mathrm{~d}$ and less than $120 \mathrm{~d}$, with no previous abortion or hormonally induced lactation, and cows not culled $<50 \mathrm{~d}$ after the last service. Lactation number and date of calving were registered.

P/AI was defined as the number of cows eligible to become pregnant that actually do get pregnant after a maximum of 10 services. Services per conception were the number of inseminations required to achieve a confirmed pregnancy. The peripartum problems considered for the analysis were abortion, RP, ketosis and metritis. Once identified the reproductive problem, the veterinarian entered the data into the health record of the cow.

\section{STATISTICAL ANALYSIS}

Initially, frequency distribution and descriptive statistics were used to explore the experimental data set for errors and outliers. After this screening, the final data set available for statistical analyses included 6,566 completed lactations. The GENMOD procedure of SAS (SAS Inst., Inc., Cary, NC) was implemented to assess the effect peripartum disease condition (present or absent) on pregnancy rate (dependent variable). To analyse factors contributing to the probability of pregnancy (binary outcome), odds of more than 3 services per pregnancy, more than 70 days for the occurrence of the first breeding and more than 120 days for the interval from calving to pregnancy, multivariable logistic regression models of SAS (SAS Inst., Inc., Cary, NC) were used, applying a backward stepwise logistic model to eliminate all non-significant explanatory variables. All of the peripartum disorders were dichotomous variables ( 0 : absent, 1: present). Variables were continuously removed from the models (four models, one for each reproductive variable analysed) by the Wald statistic criterion if the significance was greater than 0.10 . To construct the final statistical model, a preliminary full model was conducted for the following potentially explanatory variables of interest: occurrence during the pre-breeding period of mastitis, RP, metritis, abortion, ketosis and lameness. The Wald $\chi 2$ statistic was used to determine the significance of each variable that remained in the reduced model. The full statistical model included only main effects. The confounding variables month of calving and parity were included in the model as covariates. The unit of observation in this study was the health record of each cow for 1 lactation period. Services per pregnancy were classified as being $\leq 3$ or $>3$. The interval from calving to first service was categorised as lower or greater than 70 days. The interval from calving to pregnancy recorded as less or higher than 120 days.

\section{RESULTS}

Findings show that $\mathrm{CM}$ around breeding was negatively associated with P/AI; when this condition occurred before breeding cows presented a five percentage point reduction compared to those without mastitis (table 1), likewise, cows with metritis had a lower P/AI than those without this infectious disease.

The occurrence of ketosis was not associated with a significant reduction in P/AI, compared to cows not experiencing this metabolic disease. In the non-aborting cows, the pregnancy rate was increased by $10 \%(P<0.01)$ compared to aborting cows.

Also, animals with infectious interdigital disease, CM, metritis, RP, or abortions were more likely to require $>3$ services per pregnancy than cows without these problems (table 2).

Compared to cows with healthy legs, cows with infectious interdigital disease or claw horn lesions were more likely to be bred for the first time after $70 \mathrm{~d}$ postpartum (table 3). Likewise, cows with ketosis, experiencing RP

Table 1. Effect of clinical mastitis, metritis, ketosis and abortion on P/AI in 6,566 rbST-treated high producing Holstein cows in a large commercial dairy herd.

\begin{tabular}{lccc}
\hline Disease condition & P/AI $(\%)$ & $\mathrm{n}$ & $P$ value \\
\hline Clinical mastitis & & & $<0.0001$ \\
No & 41 & $1685 / 4112$ & \\
Yes & 36 & $883 / 2454$ & \\
Metritis & & & $<0.001$ \\
No & 38 & $2180 / 5737$ & \\
Yes & 33 & $274 / 829$ & \\
Ketosis & & & 0.31 \\
No & 38 & $2427 / 6388$ & \\
Yes & 34 & $61 / 178$ & \\
Abortion & & & $<0.0001$ \\
No & 46 & $286 / 6021$ & \\
Yes & 36 & $196 / 545$ & \\
\hline
\end{tabular}


Table 2. Logistic regression models for the association between infectious interdigital disease, clinical mastitis, metritis, retained placenta ketosis and abortion and odds for more than 3 services per pregnancy in growth hormone-treated high producing Holstein cows, analysed by a stepwise selection procedure on data from 6566 calvings in a large dairy herd.

\begin{tabular}{|c|c|c|c|c|c|}
\hline Risk factors & Services per pregnancy ${ }^{1}$ & $\mathrm{n}$ & Odds ratio (OR) & $P$ value & $95 \% \mathrm{CI}^{2}(\mathrm{OR})$ \\
\hline Infectious interdigital disease & & & & $<0.0001$ & \\
\hline No & $2.9 \pm 2.9$ & 5845 & 1.0 & & \\
\hline Yes & $3.2 \pm 3.1$ & 721 & 1.9 & & $1.5-3.1$ \\
\hline Clinical mastitis & & & & $<0.0001$ & \\
\hline No & $2.9 \pm 2.4$ & 4112 & 1.0 & & \\
\hline Yes & $3.1 \pm 2.5$ & 2454 & 2.2 & & $1.4-2.7$ \\
\hline Metritis & & & & 0.0045 & \\
\hline No & $2.8 \pm 2.4$ & 5737 & 1.0 & & \\
\hline Yes & $3.6 \pm 3.0$ & 829 & 1.6 & & $1.1-2.5$ \\
\hline Retained placenta & & & & $<0.0001$ & \\
\hline No & $2.9 \pm 2.5$ & 6225 & 1.0 & & \\
\hline Yes & $3.0 \pm 2.2$ & 341 & 1.6 & & $1.1-2.6$ \\
\hline Abortion & & & & 0.0019 & \\
\hline No & $2.9 \pm 2.5$ & 6021 & 1.0 & & \\
\hline Yes & $3.1 \pm 2.1$ & 545 & 2.6 & & $1.6-4.7$ \\
\hline
\end{tabular}

${ }^{1}$ Number of services required for a confirmed pregnancy.

${ }^{2}$ Confidence intervals.

Table 3. Logistic regression models for the association between infectious interdigital disease, claw horn lesions, ketosis, metritis and placental retention and odds for more than 3 services per pregnancy in growth hormone-treated high producing Holstein cows, analysed by a stepwise selection procedure on data from 6566 calvings in a large dairy herd.

\begin{tabular}{|c|c|c|c|c|c|}
\hline Risk factors & Calving-to- first service interval (d) ${ }^{1}$ & $\mathrm{n}$ & Odds ratio (OR) & $P$ value & $95 \% \mathrm{CI}^{2}(\mathrm{OR})$ \\
\hline Infectious interdigital disease & & & & 0.03 & \\
\hline No & $60 \pm 28$ & 5631 & 1.0 & & \\
\hline Yes & $63 \pm 26$ & 701 & 1.3 & & $1.1-1.5$ \\
\hline Claw horn lesions & & & & 0.01 & \\
\hline No & $60 \pm 26$ & 5887 & 1.0 & & \\
\hline Yes & $64 \pm 34$ & 445 & 1.4 & & $1.1-1.6$ \\
\hline Ketosis & & & & $<0.0001$ & \\
\hline No & $61 \pm 27$ & 6163 & 1.0 & & \\
\hline Yes & $71 \pm 34$ & 169 & 2.1 & & $1.5-2.8$ \\
\hline Endoetritis & & & & $<0.0002$ & \\
\hline No & $60 \pm 26$ & 5527 & 1.0 & & \\
\hline Yes & $66 \pm 34$ & 805 & 1.7 & & $1.4-2.0$ \\
\hline Retained placenta & & & & 0.0001 & \\
\hline No & $60 \pm 27$ & 6026 & 1.0 & & \\
\hline Yes & $67 \pm 35$ & 305 & 1.5 & & $1.2-1.9$ \\
\hline
\end{tabular}

${ }^{1}$ Days from calving-to-first service (overt estrus) after the 50-d voluntary waiting period.

${ }^{2}$ Confidence intervals.

and metritis had greater odds of being inseminated for the first time after 70 DIM.

Listed in table 4 are health problems occurring during the pre-breeding period which significantly affected the likelihood of cows becoming pregnant after 120 DIM, cows experiencing infectious interdigital disease, $\mathrm{CM}$ and metritis presented a longer interval between calving and pregnancy compared to healthy cows. 
Table 4. Logistic regression models for the association between infectious interdigital disease, claw horn lesions, clinical mastitis, and metritis and odds for conceving after 120 days in milk in growth hormone-treated high producing Holstein cows, analysed by a stepwise selection procedure on data from 6566 calvings in a large dairy herd.

\begin{tabular}{lccccc}
\hline Risk factors & Calving-to-conception interval $(\mathrm{d})^{1}$ & $\mathrm{n}$ & Odds ratio $(\mathrm{OR})^{\prime}$ & $P$ value & $95 \% \mathrm{Cl}^{2}(\mathrm{OR})$ \\
\hline No & $124 \pm 81$ & 5630 & 1.0 & & \\
Yes & $132 \pm 91$ & 701 & 1.3 & & $1.1-1.5$ \\
Claw horn lesions & $124 \pm 82$ & 5886 & 1.0 & & \\
No & $137 \pm 91$ & 445 & 1.3 & $<0.0001$ & $1.1-1.5$ \\
Yes & & & & \\
Clinical mastitis & $123 \pm 80$ & 3952 & 1.0 & & \\
No & $128 \pm 86$ & 2379 & 1.4 & & $1.2-1.6$ \\
Yes & & & & $<0.0001$ & \\
Metritis & $121 \pm 79$ & 5526 & 1.0 & & $1.8-2.4$ \\
No & $153 \pm 98$ & 805 & 2.1 & & \\
Yes & &
\end{tabular}

${ }^{1}$ Days from calving to conception as demarcated by pregnancy detection.

${ }^{2}$ Confidence intervals.

\section{DISCUSSION}

In the present study, $\mathrm{CM}$ before the time of insemination was associated with a reduction in P/AI, an increase in the number of inseminations required to establish a pregnancy and a longer interval between calving and pregnancy compared with uninfected cows prior to breeding.

Similar findings have been obtained using a small or large data set of dairy cows in temperate zones regardless of types of mastitis (Lavon et al 2011, Hertl et al 2014). The subfertility associated with mastitis does not appear to be related to the ovulation process (Morris et al 2009), but the activation of inflammatory or immune responses in the udder can lead to abnormal estrous cycle lengths (Huszenicza et al 2005, Pinzón-Sánchez and Ruegg 2011), anovulation at estrus, fertilization failure, or embryonic mortality (Moore et al 2005). This reproductive dysfunction seems to follow activation of multiple pathways that disrupt the reproductive function at the hypothalamic-pituitary axis, ovary, oocyte and the embryo (Hansen et al 2004). A variety of bioactive molecules (e.g. TNF- $\alpha$, NO, and PGF2- $\alpha$, among many others) from the infected mammary gland are released into the bloodstream which have the capacity to disrupt tissues involved in reproduction, such as the ovary (Herath et al 2007), hypothalamus (Schrick et al 2001, Nugent et al 2002), and endometrium (Herath et al 2009). Additionally, follicle growth (Herath et al 2007), and oocyte and embryonic development (Soto et al 2003) are also hampered by endotoxins. Finally, it should be noted that heat stress (Roth and Wolfenson 2016) and subclinical ketosis (Albaaj et al 2017) seem to have an additive deleterious effect together with $\mathrm{CM}$ on fertility of dairy cows.

In the present study, metritis had an important impact on fertility by decreasing P/AI, increasing services per pregnancy and calving to pregnancy intervals. The profound effect of metritis on reproductive performance of dairy cows has been amply documented (LeBlanc et al 2002, Gilbert et al 2005). Interestingly, despite the fact that metritis is associated with RP (Laven and Peters 1996, Bonneville-Hébert et al 2011), this latter puerperal disorder did not remain in the models as a factor associated with P/AI. In some studies the effect of metritis on P/AI has been more severe than in the present study, this could be due to different classifications given to metritis (LeBlanc et al 2002, Gautam et al 2009) and inaccuracy of data with observational retrospective studies, or due to multiple herds and technicians involved. In the present study, data did not suffer from such lack of precision because a single herd was used and veterinarians in charge of diagnosing and treating this disease used the same therapy to treat this periparturient disorder.

Infection of the uterus not only influences ovarian cyclicity (Sheldon et al 2002, Vieira-Neto et al 2014), but also interferes with the establishment of gestation, both by the altered immune responses that are essential at the interface between the endometrium and the embryo and the physiological presence of pus. The uterine infection also appears to disrupt the endocrine function of the endometrium and luteolysis of the ovarian corpus luteum is often delayed. Additionally, the persistence of uterine inflammation and possibly scarring of the endometrium or adhesions of the oviduct may interfere with the reproductive process.

This data demonstrated that RP was an important predisposing factor for greater number of services per pregnancy and a greater interval between calving and gestation, as previously reported by others (Ouweltjes et al 1996, Han and Kim 2005). Opsomer et al (2000) demonstrated that cows with RP tended to be at risk for 
delayed resumption of ovarian activity. Additionally, RP and metritis have been related to delayed uterine involution, likely due to a suboptimal uterine environment for conception (Galvao 2012).

In some studies, however, the intervals from calving to first service and/ or conception were not related to the occurrence of RP (Bonneville-Hébert, et al 2011, Kaneco et al 2008). On the other hand, this puerperal disorder did not affect P/AI. The lack of association of RP with $\mathrm{P} / \mathrm{AI}$ could be the appropriate therapy applied to cows in the present study, which leads to a similar reproductive performance of affected and unaffected cows. Selective treatment of cows having retained fetal membranes indicate that pregnancy rate of affected cows has been close to that of non-affected cows (Drillich et al 2006).

Our finding that RP is not related to increased risk of $\mathrm{P} / \mathrm{AI}$ is not in line with previous studies (Fourichon et al 2000, Grohn and Rajala-Schultz 2000), which have found a negative impact of RP on reproductive performance of dairy cows. However, others have reported that this puerperal disorder does not affect fertility (Kaneko et al 1997, Drillich et al 2006).

The occurrence of ketosis was an important factor affecting P/AI in this study but it affected the interval between calving and first service. These data are not in line with numerous studies on dairy cattle where elevated circulating BHBA postpartum are negatively associated with the probability of pregnancy of cows (Gohary et al 2016, Meléndez et al 2003, Walsh et al 2007). A possible explanation for this response is a better metabolic state in cows with increased feeding frequency of concentrate (Andersson et al 1991) as was the case in this study. Additionally, ketotic cows were detected after the first weeks post-calving and as the onset of ketosis post-partum delays, the impacts of ketosis on the cow fertility is less severe (McArt et al 2012).

The current analysis does not offer the magnitude and duration of postpartum hyperketonemia. However, given that cows were subjected to $3 \mathrm{x}$ milking, which led to a very high milk yield, it is believed that cows experienced a drastic negative energy balance and a high mobilization of body energy reserves early in lactation, which apparently prolonged the interval from calving to first service. This circumstance is associated with reduced hypothalamic GnRH pulse frequency and maintenance of an inappropriate negative feedback loop between estradiol levels and the required LH release necessary to support follicular growth and ovulation (Reist et al 2000, Butler 2003).

It is worth mentioning that the main diagnostic tools used to diagnose ketosis were decreased milk yield and the concentration of ketone bodies in urine, which underestimates the real incidence of this disease because the cow-side method used in the present study has low sensitivity (Geishauser et al 1998).

Several studies have shown a decreased fertility in lame dairy cows compared to non-lame cattle (Fourichon et al
2000, Meléndez et al 2003). In the present study, P/AI was not affected by this condition. A possible explanation for this discrepancy could be that early diagnosis and treatment mitigate the effect of lameness and, therefore cows did not have an increased risk of pregnancy failure. The rapid and appropriate intervention of moderately lame and lame cows have shown that conception rate of these animals has not been significantly different than that of healthy cows (Hernández et al 2005).

However, cows that became clinically lame prior to completion of their voluntary waiting period required longer intervals from calving-to-first-service and to conception. The same results have been reported by other researchers (Meléndez et al 2003, Hernández et al 2005). This could be related to negative energy balance, pain, hormonal insufficiency (Hernández et al 2001) delayed cyclicity (Garbarino et al 2004) increased incidence of ovarian cysts (Meléndez et al 2003) and reduced ovulation (Morris et al 2009).

In the present study, the risk for increased interval from calving-to-conception was similar for claw lesions (white line disease, sole ulcers) and interdigital phlegmon. On the other hand, cows with interdigital phlegmon during the voluntary waiting period had a higher probability to require more than three services than healthy cows. Thus, these data reaffirm that digital dermatitis (hairy heel warts or interdigital phlegmon) tends to be more damaging to reproductive performance than other claw lesions.

Abortion was highly associated with reduced, P/AI. This reproduction disorder has been associated with longer days to conception (Fourichon et al 2000). The effect of abortion on P/AI was possibly mediated by the occurrence of metritis and subsequently pyometra, which are associated with abortion (Ouweltjes et al 1996), and subsequently decrease reproductive performance in dairy herds. The causes of abortion were not determined. Given that cows in this herd were immunised against major cattle pathogen causing fetal losses, and that Neospora caninum was not detected with serological screening and no evidence of lesions or infections were detected in expelled fetuses, it is believed that a great proportion of abortions may have been caused by heat associated stress (Mellado et al 2016).

In conclusion, this study provides a useful insight into risk factors for fertility in dairy cows managed intensively ( $3 \mathrm{x}$ milking and the use of rbST throughout lactation) in a hot arid environment. Abortion and the occurrence of $\mathrm{CM}$ around the time of insemination, metritis and ketosis during the pre-breeding period are important risk factors for lower P/AI. The results also show that infectious interdigital disease and a variety of claw horn lesions increased the odds of requiring multiple inseminations and longer days open. Thus, in intensive dairy operations where cows are subjected to extreme heat, load minimization of health disorders under management control such as udder, uterus and hoof infections during the voluntary waiting period would improve reproductive performance. 


\section{REFERENCES}

Albaaj A, Foucras G, Raboisson D. 2017. High somatic cell counts and changes in milk fat and protein contents around insemination are negatively associated with conception in dairy cows. Theriogenology $88,18-27$.

Andersson L, Gustafsson AH, Emanuelson U. 1991 Effect of hyperketonaemia and feeding on fertility in dairy cows. Theriogenology $36,521-536$.

Bicalho RC, Warnick LD, Guard CL. 2008. Strategies to analyze milk losses caused by diseases with potential incidence throughout the lactation: A lameness example. J Dairy Sci 91, 2653-2661.

Bonneville-Hébert A, Bouchard E, Du Tremblay DD, Lefebvre R. 2011. Effect of reproductive disorder. Can J Vet Res 75, 147-151.

Butler WR. 2003. Energy balance relationship with follicular development, ovulation and fertility in postpartum dairy cows. Livest Prod Sci 83, 211-218.

Coleman DA, Thayne WV, Dailey RA. 1985. Factors affecting reproductive performance of dairy cows. J Dairy Sci 68, 1793-1803.

Dervishi E, Zhang G, Hailemariam D, Dunn SM, Ametaj BN. 2016. Occurrence of retained placenta is preceded by an inflammatory state and alterations of energy metabolism in transition dairy cows. J Anim Sci Biotechnol, 7-26.

Drillich M, Mahistedt M, Reichert U, Tenhagen BA, Heuwieser W. 2006. Strategies to improve the therapy of retained fetal membranes in dairy cows. J Dairy Sci 89, 627-635.

Dubuc J, Duffield TF, Leslie KE, Walton JS, LeBlanc SJ. 2010. Risk factors for postpartum uterine diseases in dairy cows. J Dairy Sci 93, 5764-5771.

Echternkamp SE, Thallman RM, Cushman RA, Allan MF, Gregory KE. 2007. Effects of twinning on dystocia, calf survival, calf growth, carcass traits, and cow productivity. J Anim Sci 85, 3239-3248.

Fitzgerald AM, Ryan DP, Carthy TR, Evans RD, Berry DP. 2014. Ovarian structures and uterine environment are associated with phenotypic and genetic merit for performance in lactating dairy cows. Theriogenology 82, 1231-1240.

Fourichon C, Seegers H, Malher X. 2000. Effect of disease on reproduction in the dairy cow: a meta analysis. Theriogenology 53, 1729-1759.

Fricke PM, Wiltbank MC. 1999. Effect of milk production on the incidence of double ovulation in dairy cows. Theriogenology 52, 1133-1143.

Galvão KN. 2011. Postpartum uterine diseases in dairy cows. Anim Reprod 9, 290-296.

Garbarino EJ, Hernández JA, Shearer JK, Risco CA, Thatcher WW. 2004. Effect of lameness on ovarian activity in postpartum Holstein cows. J Dairy Sci 87, 4123-4131.

Gautam G, Naka T, Yusuf M, Koike K. 2009. Prevalence of metritis during the postpartum period and its impact on subsequent reproductive performance in two Japanese dairy herds. Anim Reprod Sci 116, 175-187.

Geishauser T, Leslie K, Kelton D, Duffield T. 1998. Evaluation of five cow side tests for use with milk to detect subclinical ketosis in dairy cows. J Dairy Sci 81, 438-443.

Gilbert RO, Shin ST, Guard CL, Erb HN, Frajblat M. 2005. Prevalence of metritis and its effects on reproductive performance of dairy cows. Theriogenology 64, 1879-1888.

Gilbert RO. 2011. The effects of metritis on the establishment of pregnancy in cattle. Reprod Fertil Dev 24, 252-257.

Gohary K, Overton MW, Massow MV, LeBlanc SJ, Kerry D, et al. 2016. The cost of a case of subclinical ketosis in Canadian dairy herds. Can Vet J, 57, 728-773.

Gröhn YT, Rajala-Schultz PJ. 2000. Epidemiology of reproductive performance in dairy cows. Anim Reprod Sci 60-61, 605-614.

Han YK, Kim IH. 2005. Risk factors for retained placenta and the effect of retained placenta on the occurrence of postpartum diseases and subsequent reproductive performance in dairy cows. J Vet Sci 6, 53-59.
Hansen PJ, Soto P, Natzke RP. 2004. Mastitis and fertility in cattle possible involvement of inflammation or immune activation in embryonic mortality. Am J Reprod Immunol 51, 294-301.

Herath S, Williams EJ, Lilly ST, Gilbert RO, Dobson H, et al. 2007. Ovarian follicular cells have innate immune capabilities that modulate their endocrine function. Reproduction 134, 683-693.

Herath S, Lilly ST, Fischer DP, Williams EJ, Dobson H, Bryant CE, Sheldon IM. 2009. Bacterial lipopolysaccharide induces an endocrine switch from prostaglandin F2 $\alpha$ to prostaglandinE2 in bovine endometrium. Endocrinology 150, 1912-1920.

Hernández J, Shearer JK, Webb DW. 2001. Effect of lameness on the calving-to-conception interval in dairy cows. J Am Vet Med Assoc 218, 1611-1615.

Hernández JA, Garbarino EJ, Shearer JK, Risco CA, Thatcher WW. 2005. Comparison of milk yield in dairy cows with different degrees of lameness. J Am Vet Med Assoc 227, 1292-1296.

Huszenicza GY, Jánosi SZ, Kulcsár M, Kóródi P, Reiczigel J, et al. 2005. Effects of clinical mastitis on ovarian function in post-partum dairy cows. Reprod Dom Anim 40, 199-204.

Kaneko K, Kawakami S. 2008. Influence of experimental intrauterine infusion of Arcanobacterium pyogenes solution on ovarian activity in cycling cows. $J$ Vet Med Sci 70, 77-83.

Lavon Y, Ezra E, Leitner G, Wolfenson D. 2011. Association of conception rate with pattern and level of somatic cell count elevation relative to time of insemination in dairy cows. J Dairy Sci 94, 4538-4545.

LeBlanc SJ, Duffield TF, Leslie KE, Bateman KG, Keefe GP, et al. 2002. Defining and diagnosing postpartum clinical metritis and its impact on reproductive performance in dairy cows. J Dairy Sci 85, 2223-2236.

Lucy MC. 2001. Reproductive loss in high-producing dairy cattle: Where will it end? J Dairy Sci 84, 1277-1293.

McArt JA, Nydam DV, Oetzel GR. 2012. Epidemiology of subclinical ketosis in early lactation dairy cattle. J Dairy Sci 95, 5056-5066.

Meléndez P, Bartolomé J, Archbald LF, Donovan A. 2003. The association between lameness, ovarian cysts and fertility in lactating dairy cows. Theriogenology 59, 927-937.

Mellado M, López R, de Santiago Á, Véliz, FG, Macías-Cruz U, et al. 2016. Climatic conditions, twining and frequency of milking as factors affecting the risk of fetal losses in high-yielding Holstein cows in a hot environment. Trop Anim Health Prod 48, 1247-1252.

Moore DA, Overton MW, Chebel RC, Truscott ML, BonDurant RH. 2005. Evaluation of factors that affect embryonic loss in dairy cattle. $J$ Am Vet Med Assoc 226, 1112-1118.

Morris MJ, Walker SL, Jones DN, Routly JE, Smith RF, Dobson H. 2009. Influence of somatic cell count, body condition and lameness on follicular growth and ovulation in dairy cows. Theriogenology $71,801-806$

Nugent AM, Hatler TB, Silvia WJ. 2002. The effect of the intramammary infusion of Escherichia coli endotoxin on ovulation in lactating dairy cows. Reprod Biol 2, 295-309.

Opsomer G, Grohn YT, Hertl J, Coryn M, Deluyke H, et al. 2000. Risk factors for post partum ovarian dysfunction in high producing dairy cows in Belgium: A field study. Theriogenology 53, 841-857.

Ouweltjes W, Smolders EAA, Elving L, Van Eldik P, Schukken YH. 1996. Fertility disorders and subsequent fertility in dairy cattle. Livest Prod Sci 46, 213-220.

Pinzón-Sánchez C, Ruegg PL. 2011. Preliminary field evidence for the association of clinical mastitis with altered interestrus intervals in dairy cattle. J Dairy Sci 94, 3397-3410.

Reist M, Koller A, Busato A, Kupfer U, Blum JW. 2000. First ovulation and ketone body status in the early postpartum period of dairy cows. Theriogenology 54, 685-701.

Roche JF, Mackey D, Diskin MD. 2000. Reproductive management of postpartum cows. Anim Reprod Sci 60-61,703-712.

Roche JR, Friggens NC, Kay JK, Fisher MW, Stafford KJ, et al. 2009. Invited review: body condition score and its association with dairy cow productivity, health, and welfare. J Dairy Sci 92, 5769-5801. 
Roth Z, Wolfenson D. 2016. Comparing the effects of heat stress and mastitis on ovarian function in lactating cows: basic and applied aspects. Dom Anim Endocrinol 56, S218-S227.

Sheldon IM, Noakes DE, Rycroft AN, Pfeiffer DU, Dobson H. 2002. Influence of uterine bacterial contamination after parturition on ovarian dominant follicle selection and follicle growth and function in cattle. Reproduction 123, 837-845.

Sheldon IM, Gregory SL, LeBlanc S, Gilbert RO. 2006. Defining postpartum uterine disease in cattle. Theriogenology 65, 1516-1530.

Silva del Río N, Colloton JD, Fricke PM. 2009. Factors affecting pregnancy loss for single and twin pregnancies in a high-producing dairy herd. Theriogenology 71, 1462-1471.

Silva del Río N, Stewart S, Rapnicki P, Chang YM, Fricke PM. 2007. An observational analysis of twin births, calf sex ratio, and calf mortality in Holstein dairy cattle. J Dairy Sci 90, 1255-1264.
Soto P, Natzke RP, Hansen PJ. 2003. Actions of tumor necrosis factor- $\alpha$ on oocyte maturation and embryonic development in cattle. Am J Reprod Immunol 50, 380-388.

Vieira-Neto A, Gilbert RO, Butler WR, Santos JEP, Ribeiro ES, et al. 2014. Individual and combined effects of anovulation and cytological metritis on the reproductive performance of dairy cows. J Dairy Sci 97, 5415-5425.

Walsh RB, Walton JS, Kelton DF, LeBlanc SJ, Leslie KE, et al. 2007. The effect of subclinical ketosis in early lactation on reproductive performance of postpartum dairy cows. J Dairy Sci 90, 2788-2796.

Williams EJ, Fischer DP, Noakes DE, England GCW, Rycroft A, et al. 2007. The relationship between uterine pathogen growth density and ovarian function in the postpartum dairy cow. Theriogenology 68, 549-559. 